\title{
A meta-analysis of tunica vaginalis fascia versus dartos fascia to prevent postoperative urethrocutaneous fistula in hypospadias and fistula repair
}

\section{Hao Yang}

Zhejiang University School of Medicine https://orcid.org/0000-0002-0240-2279

Dong-lai Hu

Jinhua Municipal Central Hospital

Xiao-xiao Xuan

Zhejiang University School of Medicine

Hang Zhang

Zhejiang University School of Medicine

Qiang Shu

Zhejiang University School of Medicine Children's Hospital

Xiaodong Guo ( $\sim$ guoxiaodong@zju.edu.cn )

Research article

Keywords: Hypospadias, Urethrocutaneous fistula, Dartos fasica, Tunica vaginalis fascia, Meta-analysis

Posted Date: February 27th, 2020

DOI: https://doi.org/10.21203/rs.2.21473/v2

License: (a) (i) This work is licensed under a Creative Commons Attribution 4.0 International License. Read Full License 


\section{Abstract}

Background: Urethrocutaneous fistula (UCF) is the commonest postoperative complication in hypospadias and fistula repair. Several flap procedures have been recommended to decrease this complication rate, but no single flap procedure is ideal. The aim of this study was to compare the outcome of tunica vaginalis fascia (TVF) and dartos fascia (DF) as intermediate layers in prevention of the formation of UCF. Methods: We searched PubMed, EMBASE, the Cochrane Library and Web of Science for comparative studies up to July $1 \mathrm{st}, 2019$. Studies were selected by the predesigned inclusion criterias. The primary outcomes was UCF incidence. Results: The pooled RR with $95 \% \mathrm{Cl}$ were calculated. We extracted the relevant informations from the included studie. 9 comparative studies were included The RR of UCF rate for TVF was 0.21 (95\% Cl: 0.09-0.51, P=0.0005) compared with DF in hypospadias and fistula repair. For other postoperative complications, the RR was 0.87 (0.28-2.70, $\mathrm{P}=0.80), 1.33(0.41-4.35, \mathrm{P}=0.64)$ and $0.17(0.03-0.88, \mathrm{P}=0.04)$ for meatal stenosis/ urethral stricture, glans dehiscence/ wound dehiscence and skin necrosis, respectively. Conclusions: This meta-analysis reveals that TVF is a better option in TIP repair as compared to DF in terms of decreasing the incidence of the UCF and skin necrosis. But there is limited for other hypospadias operative techniques and fistula repair. registration number: PROSPERO CRD42019148554

\section{Introduction}

Hypospadias, which is caused by incomplete development of the urethra, is one of the most common congenital anomalies in male infants, with an estimated prevalence of 20.9 cases per 10000 male live births around the world. The international total prevalence increased 1.6 times during 1980-2010, by 0.25 cases per 10000 births per year [1]. The current purpose of hypospadias surgery is to improve the functional and cosmetic outcomes while minimizing the incidence of postoperative complications and avoiding reoperations. Urethrocutaneous fistula (UCF) is the commonest postoperative complication in hypospadias and fistula repair (0-35\%) [2] and is also a major cause of reoperation. Additional urethral coverage is now routinely used by most pediatric urologists to reduce the risk of UCF formation [3]. Dartos fascia (DF) and tunica vaginalis fascia (TVF) are the two most widely used urethral coverages with good surgical results while results varies reported by different studies [4-6]. At present, there has been no consensus on the better choice between the DF and TVF flap techniques, as well as on the shortand long-term outcomes of both techniques [3]. The aim of this meta-analysis was to compare the outcome of TVF and DF as intermediate layers in prevention of the formation of UCF in hypospadias and fistula repair.

\section{Methods}

This study is registered with PROSPERO, number CRD42019148554.

\section{Searches strategies}


Four electronic databases were searched from inceptions to July 1st, 2019, including PubMed, EMBASE, Cochrane Central and Web of Science, using Medical free words combined with hypospadias repair, hypospadias surgery, fistula* repair, urethrocutaneous fistula*,urethral fistula*, urethral cover*, soft tissue, additional cover*, subcutaneous flap*, flap cover*, dartos, tunica vaginalis.

The searching strategy in PubMed was presented as follows: (((((hypospadias repair[Title/Abstract]) OR hypospadias surgery[Title/Abstract]) OR fistula* repair[Title/Abstract]) OR urethrocutaneous fistula* [Title/Abstract]) OR urethral fistula*[Title/Abstract])) AND ((((((urethral cover*[Title/Abstract]) OR soft tissue[Title/Abstract]) OR additional cover*[Title/Abstract]) OR subcutaneous flap*[Title/Abstract]) OR flap cover*[Title/Abstract]) OR dartos[Title/Abstract]) OR tunica vaginalis[Title/Abstract]). We also screened clinicaltrials.gov, some international professional conference abstract (such as the Society for Pediatric Urology, European Socitey for Paediatric Urology, Asia-Pacific Association of Pediatric Urologists, American Pediatric Surgical Association and World Federation of Associations of Pediatric Surgery) and the references of included articles and published reviews to identify additional relevant publications.

\section{Inclusion criteria}

The studies were selected according to the following criteria: (1) participants were diagnosed as hypospadias or fistula, (2) reported the incidence of postoperative UCF with or without the incidence of other complications, (3) comparative studies with control groups will be included in the review, (4) the article was written in English. Complications were defined as UCF, meatal stenosis, urethral stricture, glans dehiscence, wound dehiscence or skin necrosis. The primary outcomes was fistula incidence (the proportion of patients who formed UCF postoperatively). The secondary outcomes were incidences of other complications (the proportion of patients who formed meatal stenosis, urethral stricture, glans dehiscence, wound dehiscence and skin necrosis postoperatively).

\section{Data extraction and quality assessment}

Two independent authors (HY, QS) screened all retrieved titles and abstracts according to the predescribed inclusion criteria to identify potentially eligible studies. After screening, we accessed the full text to determine the final included studies independently. The following data from each included study were extracted: study characteristics (first author, published year, study design, hypospadias type, surgery type, and follow up time), patient characteristics (patients numbers, patients age, incidence of fistula, incidence of other complications). For the whole process, discrepancies were resolved by discussion between the two reviewers and reevaluation with a third author (XG). The level of evidence and publication type was classified according to the Oxford CEBM [7].

\section{Statistical analysis}

We used RevMan 5.3 (Cochrane Library, Oxford, UK) and STATA 13.1 (Corp LP, College Station, TX, USA) softwares to perform this meta-analysis and relevant subgroup analysis. All categorical data were 
analyzed by estimating the pooled risk ratios (RR) and 95\% confidence intervals (Cl). The MantelHaenszel method was used to calculate pooled RR [8]. Heterogeneity was evaluated by the Cochrane's Qstatistic and the $I^{2}$ statistic [9]. A random-effects model would be used if heterogeneity was significant (the $Q$ statistic was significant or $\mathrm{I}^{2}$ values $>50 \%$ ). Otherwise, a fixed-effects model would be used. Sensitivity analysis and subgroup analysis were performed to assess the robustness of the results and find the possible sources of heterogeneity. Several subgroup analysis were conducted, including different surgery type, study design and other available groups. The symmetry of funnel plot was used to judge the existence of publication bias subjectively. And Begg and Egger tests $[10,11]$ were conducted to measure the potential publication bias through STATA software. A $P$ values $<0.05$ was considered to be statistically significant.

\section{Results}

\section{Literature selection and study characteristics}

Of 1928 databases articles titles and 57 trial register titles screened, 1269 abstracts were reviewed, 31 full text were reviewed, and 9 articles [12-20] met our inclusion criteria and were included in our meta-analysis (Fig. 1). The 9 comparative studies involving a total of 564 hypospadias or fistula patients (193 patients in the TVF group and 371 in DF group). Two studies included distal and midshaft hypospadias [12, 16], 1 for proximal [19], 2 [18, 20]included hypospadias and fistula patients, 4 [13-15, 17] included all type hypospadias. Most studies performed one-stage TIP urethroplasty for primary hypospadias except 1 [19] for staged transverse preputial island flap urethroplasty and $2[18,20]$ included fistula repair. 5 studies $[12,13,15,17,18]$ used optical magnification amplifier while $1[14]$ not used and 3 unknown $[16,19,20]$. For all postoperative complications, such as UCF, skin necrosis, meatal stenosis, glans or wound dehiscence, urethral stricture, diverticula, scrotal edema and so on, we divided into 2 categories (UCF and other complications). (Table 1)

\section{Meta-analysis}

A total of 9 comparative studies [12-20], comprising 564 patients with hypospadias or fistula, were included. All studies reported the incidence of postoperative UCF. The RR of fistula for TVF was 0.21 (95\% $\mathrm{Cl}: 0.09-0.51, P=0.0005)$ compared with DF in hypospadias and fistula repair. The heterogeneity was statistically not significant $\left(P=0.77, \mathrm{I}^{2}=0 \%\right.$ ) (Fig. 2a), and the fixed effect model was used for analysis. The difference in the incidence of total other complications (other than fistula) was not significant (RR=1.16, 95\% Cl: 0.64-2.09) (Fig. 2b) while comparing TVF to DF groups. For other complications, the pooled RR for meatal stenosis/urethral stricture, glans dehiscence/wound dehiscence and skin necrosis was 0.87 (95\% Cl: 0.28-2.70, $P=0.80$ ) (Fig. 3a), 1.33 (95\% Cl: 0.41-4.35, $P=0.64$ ) (Fig. 3b) and 0.17 (95\% Cl: $0.03-0.88, P=0.04$ ) (Fig. $3 c$ ), the heterogeneity was all statistically not significant ( all $I^{2}$ were equal to $0 \%$ in both primary and secondary outcomes). Of the included studied, 8 comparative studies reported other complications of hypospadias or fistula repair, including meatal stenosis $(n=10)$, urethral stricture $(n=11)$, glans or wound dehiscence $(n=9)$, skin necrosis $(n=12)$, scrotal edem $(n=5)$, penile tilt $(n=4)$, 
diverticula( $(n=2)$, residual chordee $(n=2)$ and bladder $\operatorname{spasm}(n=1), 2$ studies reported total other complications but were not mentioned in each group (Table 2.).

Although an asymmetry was observed in funnel plot (Fig. 4), both the Begg and the Egger's test indicated no significant publication bias in our meta-analysis, with $P$ value equal to 1.00 and 0.82 respectively. Moreover, sensitivity analysis indicated that omitting any one study did not significantly influence our results, which stabilized the meta-analysis results.

In the subgroup analysis (Table 3 ) of different surgery type, the RR was 0.15 (95\% Cl: 0.05-0.46, $P=0.0005)$ for TIP group. The RR of one-stage hypospadias repair or fistula repair was 0.19 (0.07-0.50, $P=0.0008)$ while was $0.36(0.05-2.83, P=0.33)$ for staged urethroplasty. The RR was $0.16(0.03-0.86$, $P=0.03)$ and $0.23(0.08-0.65, P=0.006)$ in RCT and cohort studies respectively. According whether magnification technique was used intraoperatively, we classified all studies as "Yes" and "No or NA", and the RR were $0.17(0.05-0.60, P=0.006)$ and $0.28(0.08-0.91, P=0.03)$ respectively. These results showed that in TIP urethroplasty, one-stage urethroplasty, with or without magnification technique, TVF had lower postoperative UCF rate compared with DF as a soft tissue coverage in the hypospadias and fistula repair. But staged urethroplasty had no significant difference between TVF and DF.

\section{Discussion}

This meta-analysis was the most comprehensively synthesis of evidence for currently available comparison between DF and TVF flap techniques for hypospadias and fistula patients in comparative studies. We included 9 comparative studies, comprising 564 patients performed hypospadias or fistula repair with the use of DF or TVF flaps. Evidence of our findings came from the pooled estimate size for the outcomes, which showed that TVF was better than DF for the repair of hypospadias and fistula in terms of UCF ( $R R=0.21,95 \% \mathrm{Cl}: 0.09-0.51)$ and skin necrosis ( $\mathrm{RR}=0.17,95 \% \mathrm{Cl}$ : 0.03-0.88). No significant difference was found in meatal stenosis/urethral stricture (RR=0.87, 95\% Cl: $0.28-2.70)$ and glans dehiscence/wound dehiscence ( $R R=1.33,95 \% \mathrm{Cl}$ : 0.41-4.35). No significant statistically difference was found in different surgery type, study design, with or without magnification technique subgroups. In addition, publication bias test verified the robustness of the results in this meta-analysis. Reoperation for failed hypospadias or fistula repair has been considered to be a seriously problem because the dense fibrotic tissue causes difficulties in wound healing and increases the rate of complications [21]. Various surgical methods and modifications have been developed for repairing the hypospadias and fistula while UCF are still one of the most common complications of these techniques [22]. The total UCF rate is $7.71 \%$ in our study, consistent with the $7.5 \%$ incidence in a systematic review [2]. Patients age, glans size, urethral defect length, urethral operation history, surgical procedure, type of surgical repair, chordee degree, magnification technique, caudal anesthesia, preoperative hormonal stimulation and other many factors are may related to the development of UCF and other complications postoperatively [21-25]. Additional soft coverages on the neourethra are also introduced to avoid these complications especially for decreasing the incidence of postoperative UCF. TVF, DF, Buck's fascia, spongious tissue, external spermatic fascia, adipose tissue of scrotum, adipose tissue of speramtic cord, combination of tissues 
and paltelet rich plasma are used in different studies [26-32] with various outcomes. Among them, TVF and DF are the most popular flaps in the repair of hypospadias and fistula.

DF is a layer of connective tissue found in the penile dorsal or ventral, foreskin, and scrotum and can be used in hypospadias or fistula repair in different techniques [33,34]. TVF can be harvested through penile incision by degloving till the root of penis [26] or additional scrotal incision which reach and cover the neourethra through a subcutaneous scrotal tunnel [35]. Excellent vascularity, easy availability and adequate source are advantages of DF, making this flap technique more popular for many pediatric urologists especially for young surgeons. Penile rotation and preputial skin necrosis were common reported relevant complications in the use of DF and could be avoided by careful operation and technical improvement. Harvest of TVF, however, may damage to the vas or vessels of the testicular therefore resulting in scrotal abscess or scrotal hematoma but finally no reported in all of the included studies. Snodgrass described additional interposition of vascularized tissues between the tubularized plate and glans closure dissected from dorsal prepucial and shaft skin [36]. Duckett has described that when dartos is separated from skin, it compromises the vascularity of the overlying skin [37]. So the dissection of DF may compromise the vascularity of the preputial skin covering and result in subsequent skin necrosis. This is consistent with the conclusion of our secondary outcomes. The blood supply of the neourethra tissue may be affected due to the dissection and utilization of DF, which mainly comes from the shortage of dartos or preputial skin necrosis. Although skin necrosis was inconsequential in the long run, it did cause anxiety and distress to the families and invited more hospital visits. Moreover, dissection to raise DF may damaging the intrinsic blood supply to the outer skin, which transposed ventrally to provide skin cover may consequently devitalize leading to skin necrosis, and fistula formation. However, this is rarely affected in TVF technique for its ventral skin covering is rarely compromised. All these can theoretically explain the advantage of TVF over DF. And we performed this meta-analysis to prove the advantages of TVF over DF with the data.

The results of our meta-analysis were partially consistent with the result of a systematic review by Fahmy et al [30]. However, there were several differences among the two studies. The study of Fahmy et al included not only comparative studies but cases series, it weakened the evidence. In addition, literature retrieval process should be as comprehensive as possible while there is only one database (PubMed) in his study. Our included only comparative studies and searched 4 databases (PubMed, EMBASE, the Cochrane Library and Web of Science), a clinical trial register(clinicaltrial.gov) and several international meeting abstract archives. All these enhanced our evidence.

There are several limitations in our meta-analysis. Firstly, although a comprehensive retrieval was performed, only limited studies without any unpublished study was included, which might bias the results. Secondly, the durations of follow-up varied, ranging from 6 months to 10.5 years. The relatively short length of follow-up limited the present study, as it is known that long-term follow-up is necessary to determine the true complication rate of hypospadias repair and Spinoit et al [38] stated in their study that only $47.37 \%$ complications appeared in the first year. Thirdly, the definition of complications was inconsistent among all included studies, with some including skin necrosis, others not. And some 
complication such as meatal retraction, functional and cosmetic results were not reported in all of the included studies. Which indicated that reporting complications also depended on different factors and the publication bias existed. A survey of North American pediatric urologists clearly showed that there is a discrepancy between complication rates reported in the literature and the participants' operative outcomes, regardless of practice setting, operative volume, or time in practice [39]. Lastly, other than follow-up periods and complications criteria, differences in other clinical characteristics including study settings, patients age, thickness and width of flap, hypospadias type and surgery type existed, although statistical heterogeneity was not high (CEBM levels of evidence: $1 b$ to $2 b$ ). The contribution of these differences to final outcomes was unknown. We performed subgroup analyses to find potential sources of heterogeneity but no significant results were found due to the limited number of studies.

Although many uncontrollable confounders factors may affect the hypospadias surgery outcomes especially the wide variability for individual surgical experience and complexity for hypospadias cases, more large sample size, well-designed, single-urologist prospective studies need to be conducted for optimal comparison between this two flap techniques.

\section{Conclusions}

TVF is a better option in TIP repair as compared to DF in terms of decreasing the incidence of the UCF and skin necrosis. But there is limited evidence for other hypospadias operative techniques and fistula repair.

\section{Abbreviations}

UCF: urethrocutaneous fistula; DF: dartos fascia; TVF: tunica vaginalis fascia; RR: risk ratio: Cl: confidence intervals

\section{Declarations}

\section{Ethics approval and consent to participate}

Not applicable.

\section{Consent for publication}

Not applicable.

\section{Availability of data and materials}

All data generated or analyzed during this study are included in this published article.

\section{Competing interests}


The authors declare that they have no competing interests.

\section{Funding}

No funds were received in support of this study.

\section{Authors' contributions}

Manuscript writing and editing: $H Y, D H, Q S$ and $X G$. Project development: $X G$. Data collection: $H Y, D H, X X$ and QS, data management/analysis: $\mathrm{HY}$ and $\mathrm{HZ}$. All authors reviewed the manuscript. All authors read and approved the final manuscript.

\section{Acknowledgements}

None.

\section{References}

1. Yu X, Nassar N, Mastroiacovo P, Canfield M, Groisman B, Bermejo-Sánchez E, et al. Hypospadias Prevalence and Trends in International Birth Defect Surveillance Systems, 1980-2010. Eur Urol. 2019;76(4):482-90.

2. Hardwicke JT, Bechar JA, Hodson J, Osmani O, Park AJ. Fistula after single-stage primary hypospadias repair - A systematic review of the literature. J Plast Reconstr Aesthet Surg. 2015;68(12):1647-55.

3. Fahmy O, Khairul-Asri MG, Schwentner C, Schubert T, Stenzl A, Zahran MH, et al. Algorithm for optimal urethral coverage in hypospadias and fistula repair: A systematic review. Eur Urol. 2016;70(2):293-8

4. Cheng EY, Vemulapalli SN, Kropp BP, Pope JC 4th, Furness PD 3rd, Kaplan WE, et al. Snodgrass hypospadias repair with vascularized dartos flap: the perfect repair for virgin cases of hypospadias? J Urol. 2002;168(4 Pt 2):1723-6; discussion 1726.

5. Chandrasekharam VV. Comparative study of dartos fascia and tunica vaginalis pedicle wrap for the tubularized incised plate in primary hypospadias repair. BJU Int. 2005;95(6):909-10.

6. Landau EH, Gofrit ON, Meretyk S, Katz G, Golijanin D, Shenfeld OZ, et al. Outcome analysis of tunica vaginalis flap for the correction of recurrent urethrocutaneous fistula in children. J Urol. 2003;170(4 Pt 2):1596-9; discussion 1599.

7. Oxford Centre for Evidence-based Medicine Levels of Evidence. 2001. https://www.cebm.net/2009/06/oxford-centre-evidence-based-medicine-level s-evidence-march2009/. Accessed 22 Dec 2019.

8. Mantel N, Haenszel W. Statistical aspects of the analysis of data from retrospective studies of disease. J Natl Cancer Inst. 1959;22(4):719-48. 
9. Higgins JPT, Green S. Cochrane Handbook for SystematicReviews of Interventions Version 5.1.0. 2011. http://handb ook-5-1.cochrane.org/. Accessed 25 Dec 2019.

10. Begg C, Mazumdar M. Operating characteristics of a rank correlation test for publication bias. Biometrics. 1994;50(4):1088-101.

11. Egger M, Davey Smith G, Schneider M, Minder C. Bias in meta-analysis detected by a simple, graphical test. BMJ. 1997;135(7109):629-34.

12. Babu $R$, Hariharasudhan $S$. Tunica vaginalis flap is superior to inner preputial dartos flap as a waterproofing layer for primary TIP repair in midshaft hypospadias. J Pediatr Urol. 2013;9(6 Pt A):804-7.

13. Basavaraju M, Balaji DK. Choosing an ideal vascular cover for Snodgrass repair. Urol Ann. 2017;9(4):348-52.

14. Chatterjee US, Mandal MK, Basu S, Das R, Majhi T. Comparative study of dartos fascia and tunica vaginalis pedicle wrap for the tubularized incised plate in primary hypospadias repair. BJU Int. 2004;94(7):1102-4.

15. Dhua AK, Aggarwal SK, Sinha S, Ratan SK. Soft tissue covers in hypospadias surgery: Is tunica vaginalis better than dartos flap? J Indian Assoc Pediatr Surg. 2012;17(1):16-9.

16. Gajbhiye V, Singh N, Singh S, Verma RS. Tunica vaginalis flap (TVF) as an alternative to dartos flap in primary hypospadias repair-our experience. J Evolution Med Dent Sci. 2018;7(16):1970-3.

17. Kurbet SB, Koujalagi RS, Geethika V, Nagathan V. A 1-year randomized controlled trial to compare the outcome of primary repair of hypospadias with vascular cover using tunica vaginalis flap with those using preputial dartos fascia. Afr J Paediatr Surg. 2018;15(1):42-7.

18. Richter F, Pinto PA, Stock JA, Hanna MK. Management of recurrent urethral fistulas after hypospadias repair. Urol. 2003;61(2):448-51.

19. Wang $\mathrm{C}$, Song $\mathrm{H}$, Zhang W. Staged transverse preputial island flap urethroplasty for proximal hypospadias: a single-center experience. Pediatr Surg Int. 2019;35(7):823-7.

20. Xiao Y, Lv J, Yang $H$. The use and effect of subcutaneous flap and tunica vaginalis flap technique in hypospadias repair and hypospadias fistulas repair. Chin J Urol. 2005;26(3):205-7.

21. Snodgrass W, Bush NC. Re-operative urethroplasty after failed hypospadias repair: how prior surgery impacts risk for additional complications. J Pediatr Urol. 2017;13(3):289.e1-289.e6.

22. Dokter EM, Mouës CM, Rooij IALMV, Biezen JJV. Complications after hypospadias correction: prognostic factors and impact on final clinical outcome. Eur J Pediatr Surg. 2018;28(2):200-6.

23. Yildiz T, Tahtali IN, Ates DC, Keles I, Ilce Z. Age of patient is a risk factor for urethrocutaneous fistula in hypospadias surgery. J Pediatr Urol. 2013;9(6 Pt A):900-3.

24. Bush NC, Villanueva C, Snodgrass W. Glans size is an independent risk factor for urethroplasty complications after hypospadias repair. J Pediatr Urol. 2015;11(6):355.e1-355.e5.

25. Rynja SP, de Jong TPVM, Bosch JLHR, de Kort LMO. Testosterone prior to hypospadias repair: Postoperative complication rates and long-term cosmetic results, penile length and body height. $\mathrm{J}$ 
Pediatr Urol. 2018;14(1):31.e1-31.e8.

26. Snow BW. Use of tunica vaginalis to prevent fistula in hypospadas. J Urol. 1986;136(4):861-3.

27. Churchill BM, van Savage JG, Khoury AE, McLorie GA. The dartos flap as an adjunct in preventing urethrocutaneous fistula in repeat hypospadias surgery. J Urol. 1996;156(6):2047-9.

28. Yerkes EB, Adams MC, Miller DA, Pope JC 4th, Rink RC, Brock JW 3rd. Y-to-I Wrap: Use of the distal spongiosum for hypospadias repair. J Urol. 2000;163(5):1536-8; discussion 1538-9.

29. Yamataka A, Ando K, Lane GJ, Miyano T. Pedicled external spermatic fascia flap for urethroplasty in hypospadias and closure of urethrocutaneous fistula. J Pediatr Surg. 1998;33(12):1788-9.

30. Seo S, Ochi T, Yazaki Y, Okawada M, Doi T, Miyano G, et al. Soft tissue interposition is effective for protecting the neourethra during hypospadias surgery and preventing postoperative urethrocutaneous fistula: a single surgeon's experience of 243 cases. Pediatr Surg Int. 2015;31(3):297-303.

31. Bilici S, Sekmenli T, Gunes M, Gecit I, Bakan V, Isik D. Comparison of dartos flap and dartos flap plus spongioplasty to prevent the formation of fistulae in the Snodgrass technique. Int Urol Nephrol. 2011;43(4):943-8.

32. Mahmoud AY, Gouda S, Gamaan I, Baky Fahmy MA. Autologous platelet-rich plasma covering urethroplasty versus dartos flap in distal hypospadias repair: A prospective randomized study. Int $J$ Urol. 2019;26(4):475-80.

33. Jia W1, Liu GC, Zhang LY, Wen YQ, Fu W, Hu JH, et al. Comparison of tubularized incised plate urethroplasty combined with a meatus-based ventral dartos flap or dorsal dartos flap in hypospadias. Pediatr Surg Int. 2016;32(4):411-5.

34. Erol A, Kayikci A, Memik O, Cam K, Akman Y. Single vs. double dartos interposition flaps in preventing urethrocutaneous fistula after tubularized incised plate urethroplasty in primary distal hypospadias: a prospective randomized study. Urol Int. 2009;83(3):354-8.

35. Pescheloche P, Parmentier B, Hor T, Chamond O, Chabaud M, Irtan S, et al. Tunica vaginalis flap for urethrocutaneous fistula repair after proximal and mid-shaft hypospadias surgery: A 12-year experience. J Pediatr Urol. 2018;14(5):421.e1-421.e6.

36. Snodgrass W. Tubularized incised plate urethroplasty in distal hypospadias. J Urol. 1994;151(2):4645.

37. Duckett JW. In: Walsh PC, Retik AB, Vaughan ED, Wein AJ, editors. Campbell's Urology. Philadelphia: Academic; 1998.p. $2094-2116$.

38. Spinoit AF, Poelaert F, Groen LA, Van Laecke E, Hoebeke P. Hypospadias repair at a tertiary care center: long-term followup is mandatory to determine the real complication rate. J Urol. 2013;189(6):2276-81.

39. Prasad MM, Marks A, Vasquez E, Yerkes EB, Cheng EY. Published surgical success rates in pediatric urology--fact or fiction?. J Urol. 2012;188(4 Suppl):1643-7. 


\section{Tables}

Table 1 Summarizes the primary characteristics of the included trials 


\begin{tabular}{|c|c|c|c|}
\hline $\begin{array}{l}\text { Hypospadias type Surgery type } \\
\text { LOE }\end{array}$ & $\begin{array}{l}\text { Age Follow-up } \\
\text { (ms) }\end{array}$ & Magnification UCF & $\begin{array}{l}\text { Other } \\
\text { complications }\end{array}$ \\
\hline
\end{tabular}

l 2b distal and $\quad$ TIP, primary 83 9- median: $182.5 \times$ Loupse TVF: TVF: 1 glans

2] midshaft repair, 1-stage 18 (18-20) $1 / 21$ dehiscence, 1

m $\quad$ DF: meatal stenosis

11/62 DF: 6 skin

necrosis, 2

glans

dehiscence, 4

meatal stenosis

\begin{tabular}{|c|c|c|c|c|c|c|c|}
\hline $\begin{array}{l}\text { ju } \\
7)\end{array}$ & $\begin{array}{l}\text { distal, mid penile } \\
\text { and proximal }\end{array}$ & $\begin{array}{l}\text { TIP, primary } \\
\text { repair,1-stage }\end{array}$ & 83 & $\begin{array}{l}1.6-6-36 \\
12 \\
y\end{array}$ & $2.5 \times$ Loupse & $\begin{array}{l}\text { TVF: } \\
0 / 26 \\
\text { DF: } \\
11 / 57\end{array}$ & $\begin{array}{l}\text { TVF: } 5 \text { mild } \\
\text { scrotal edema } \\
\text { DF: } 3 \text { glans } \\
\text { breakdown, } 1 \\
\text { meatal stenosis }\end{array}$ \\
\hline e et $2 b$ & $\begin{array}{l}\text { distal, mid penile } \\
\text { and proximal }\end{array}$ & $\begin{array}{l}\text { TIP, primary } \\
\text { repair,1-stage }\end{array}$ & 49 & $\begin{array}{ll}1- & \text { mean: } 24 \\
22 & (12-48) \\
y & \end{array}$ & Not used & $\begin{array}{l}\text { TVF: } \\
0 / 29 \\
\text { DF: } \\
3 / 20\end{array}$ & $\begin{array}{l}\text { TVF: } 1 \text { wound } \\
\text { dehiscence } \\
\text { DF: } 0\end{array}$ \\
\hline $\begin{array}{ll}\text { l } & 1 \mathrm{~b} \\
5] & \end{array}$ & $\begin{array}{l}\text { distal, mid penile } \\
\text { and proximal }\end{array}$ & $\begin{array}{l}\text { TIP } \\
\text { primary repair, 1- } \\
\text { stage }\end{array}$ & 50 & $\begin{array}{l}132 \text { NA } \\
\mathrm{m}\end{array}$ & $2.5 \times$ Loupse & $\begin{array}{l}\text { TVF: } \\
0 / 25 \\
\text { DF: } \\
3 / 25\end{array}$ & $\begin{array}{l}\text { TVF: } 1 \text { wound } \\
\text { dehiscence, } 1 \\
\text { bladder spasm } \\
\text { DF: } 3 \text { skin } \\
\text { necrosis }\end{array}$ \\
\hline $1 \mathrm{~b}$ & $\begin{array}{l}\text { distal and mid } \\
\text { penile }\end{array}$ & $\begin{array}{l}\text { TIP } \\
\text { primary repair, 1- } \\
\text { stage }\end{array}$ & 48 & $\begin{array}{l}18-6-18 \\
52 \\
m\end{array}$ & NA & $\begin{array}{l}\text { TVF: } \\
0 / 24 \\
\text { DF: } \\
3 / 24\end{array}$ & $\begin{array}{l}\text { TVF: } 4 \text { ventral } \\
\text { penile tilt, } 1 \\
\text { wound } \\
\text { dehiscence } \\
\text { DF: } 3 \text { skin } \\
\text { necrosis }\end{array}$ \\
\hline $\begin{array}{cc}\text { al } & 1 \mathrm{~b} \\
7] & \end{array}$ & $\begin{array}{l}\text { distal, mid penile } \\
\text { and proximal }\end{array}$ & $\begin{array}{l}\text { TIP } \\
\text { primary repair, 1- } \\
\text { stage }\end{array}$ & 40 & $\begin{array}{ll}9 & >6 \\
m^{-} & \\
18 & \\
y & \end{array}$ & $2.5 \times$ Loupse & $\begin{array}{l}\text { TVF: } \\
0 / 20 \\
\text { DF: } \\
2 / 20\end{array}$ & $\begin{array}{l}\text { TVF: } 1 \text { urethral } \\
\text { stricture, } 2 \\
\text { meatal stenosis } \\
\text { DF: } 1 \text { urethral } \\
\text { stricture, } 2 \\
\text { meatal stenosis }\end{array}$ \\
\hline
\end{tabular}

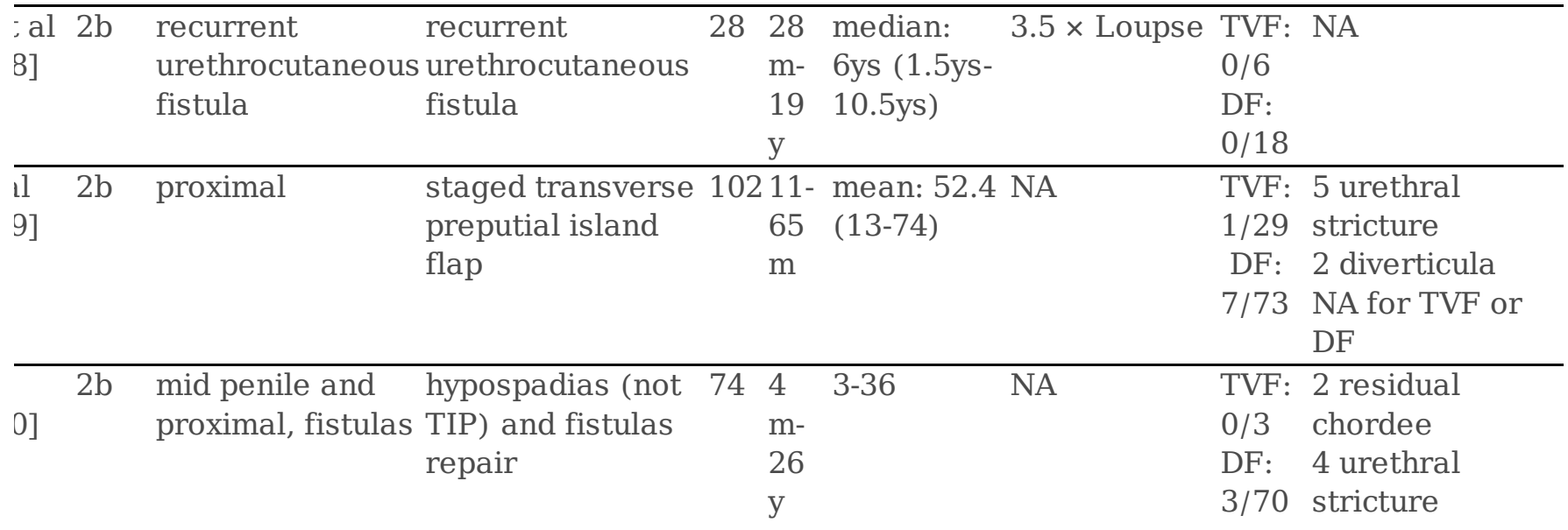


LOE: level of evidence, UCF: urethrocutaneous fistual, TIP: tubularized incised plate, NA: not available.

Table 2 Complications of hypospadias and fistula repair in all included studies $(N=584)$

\begin{tabular}{lll}
\hline Complication & $\mathrm{n}(\%)$ & $\mathrm{n} / \mathbf{N}(\%)$ \\
\hline UCF & $45(44.55)$ & 7.71 \\
Skin necrosis & $12(11.88)$ & 2.05 \\
Urethral stricture & $11(10.89)$ & 1.88 \\
Meatal stenosis & $10(9.90)$ & 1.71 \\
Glans/wound dehiscence & $9(8.91)$ & 1.54 \\
Scrotal edem & $5(4.95)$ & 0.86 \\
Penile tilt & $4(3.96)$ & 0.68 \\
Diverticula & $2(1.98)$ & 0.34 \\
Others & $3(2.97)$ & 0.51 \\
Total & $101(100 \%)$ & $17.29 \%$ \\
\hline
\end{tabular}

UCF: urethrocutaneous fistual, n: number of a complication, $N$ : number of total complications

Table 3 Subgroup analyses for meta-analysis

\begin{tabular}{|c|c|c|c|c|}
\hline Subgroup & n (studies) & $\mathbf{N}$ (patients) & RR (95\% CI) & $P$ \\
\hline All patients & 9 & 564 & $0.21(0.09-0.51)$ & 0.0005 \\
\hline \multicolumn{5}{|l|}{ Surgery type } \\
\hline TIP & 6 & 353 & $0.15(0.05-0.46)$ & 0.0007 \\
\hline One-stage & 8 & 461 & $0.19(0.07-0.50)$ & 0.0008 \\
\hline Staged & 1 & 103 & $0.36(0.05-2.83)$ & 0.33 \\
\hline \multicolumn{5}{|l|}{ Study design } \\
\hline RCT and non-RCT & 3 & 138 & $0.16(0.03-0.86)$ & 0.03 \\
\hline Cohort studies & 6 & 426 & $0.23(0.08-0.65)$ & 0.006 \\
\hline \multicolumn{5}{|l|}{ Magnification } \\
\hline Yes & 5 & 291 & $0.17(0.05-0.60)$ & 0.006 \\
\hline No or NA & 4 & 273 & $0.28(0.08-0.91)$ & 0.03 \\
\hline
\end{tabular}

n: number of studies, N: number of patients, TIP: tubularized incised plate, RCT: randomized controlled trials, NA: not available

\section{Additional File Legends}

Additional file 1: Figure S1. Sensitivity analysis

Additional file 2: Table S2. PRISMA Checklist

Figures 


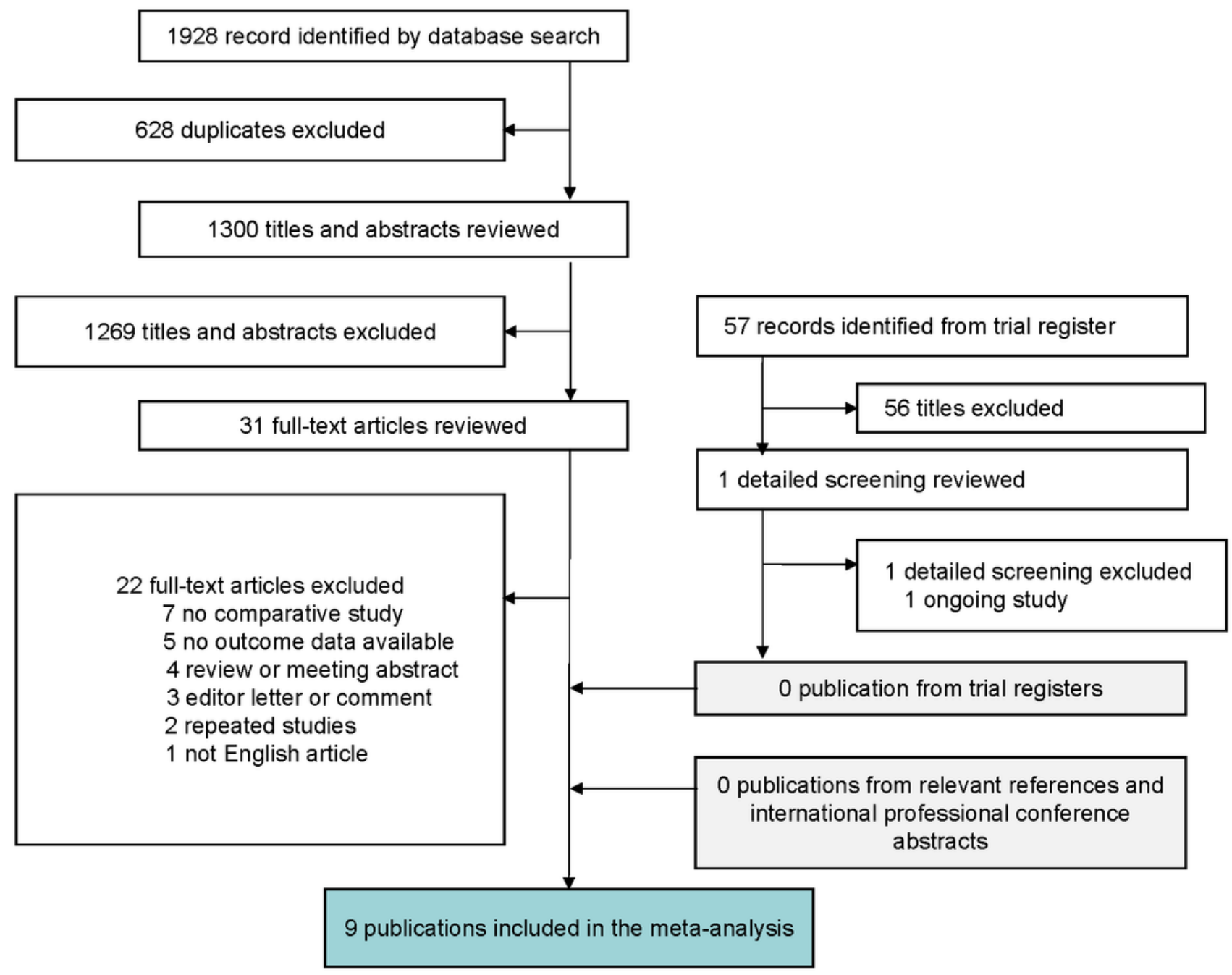

Figure 1

Study selection 
A

\begin{tabular}{|c|c|c|c|c|c|c|c|c|c|}
\hline Study or Subgroup & $\begin{array}{l}\text { TVF } \\
\text { Events }\end{array}$ & Iotal & $\begin{array}{l}\text { DF } \\
\text { Events }\end{array}$ & Iotal & Weight & $\begin{array}{l}\text { Risk Ratio } \\
\text { M-t. Flxed. } 95 \% \text { CI }\end{array}$ & $\begin{array}{r}\text { Risk } \\
\text { M-H. Fixe }\end{array}$ & $\begin{array}{l}\text { Ratio } \\
\text { ad. } 95 \% \mathrm{cL}\end{array}$ & \\
\hline Babu et al (2013) & 1 & 21 & 11 & 62 & $18.1 \%$ & $0.27[0.04,1.96]$ & & E & \\
\hline Basavaraju et al (2017) & 0 & 26 & 11 & 57 & $23.7 \%$ & $0.09[0.01,1.53]$ & & & \\
\hline Chatterjee et al (2004) & 0 & 29 & 3 & 20 & $13.4 \%$ & $0.10[0.01,1.84]$ & & & \\
\hline Dhua et al (2012) & 0 & 25 & 3 & 25 & $11.4 \%$ & $0.14[0.01,2.63]$ & & & \\
\hline Gajbbiye et al (2018) & 0 & 24 & 3 & 24 & $11.4 \%$ & $0.14[0.01,2.62]$ & & & \\
\hline Kurbet et al (2018) & 0 & 20 & 2 & 20 & $8.1 \%$ & $0.20[0.01,3.92]$ & & & \\
\hline Richter et al (2003) & 0 & 16 & 0 & 19 & & Not estimable & & & \\
\hline Wang et al (2019) & 1 & 29 & 7 & 74 & $12.8 \%$ & $0.36[0.05,2.83]$ & & & \\
\hline Xao et al (2005) & 0 & 3 & 3 & 70 & $1.2 \%$ & $2.54[0.16,41.15]$ & & & \\
\hline Total $(95 \% \mathrm{Cl})$ & & 193 & & 371 & $100.0 \%$ & $0.21[0.09,0.51]$ & & & \\
\hline Total events & 2 & & 43 & & & & & & \\
\hline $\begin{array}{l}\text { Heterogeneily: } \mathrm{Ch}^{\mathrm{P}}=4 \text {. } \\
\text { Test for overal effect: }\end{array}$ & $\begin{array}{l}\mathrm{df}=7(\mathrm{P} \\
3.49(\mathrm{P}=0\end{array}$ & $\begin{array}{l}=0.77) \\
.0005)\end{array}$ & $; 1^{2}=0 \%$ & & & & $\begin{array}{c}0.1 \\
\text { Favours [TVF] }\end{array}$ & $1{ }^{1} 10$ & 500 \\
\hline
\end{tabular}

B

\begin{tabular}{|c|c|c|c|c|c|c|c|c|c|}
\hline Study or Subqreup & $\begin{array}{l}\text { TVF } \\
\text { Events }\end{array}$ & Ietal _ & $\begin{array}{l}\text { DF } \\
\text { Events }\end{array}$ & Iotal & Weight & $\begin{array}{l}\text { Risk Ratio } \\
\text { M-H. Fixed. } 25 \% \mathrm{Cl}\end{array}$ & $\begin{array}{r}\text { Risk h } \\
M-H \text {. Fixer }\end{array}$ & $\begin{array}{l}\text { Ratio } \\
\text { ad. } 95 \% \mathrm{Cl}\end{array}$ & \\
\hline Babu et al (2013) & 2 & 21 & 12 & 62 & $33.4 \%$ & $0.49[0.12,2.02]$ & & & \\
\hline Basavaraju et al (2017) & 5 & 26 & 4 & 57 & $13.8 \%$ & $2.74[0.80,9.38]$ & & & \\
\hline Chatterjee et al (2004) & 1 & 29 & 0 & 20 & $3.2 \%$ & $2.10[0.09,49.09]$ & & & \\
\hline Dhua et al (2012) & 2 & 25 & 3 & 25 & $16.5 \%$ & $0.67[0.12,3.65]$ & & & \\
\hline Gajbbiye et al (2018) & 5 & 24 & 3 & 24 & $16.5 \%$ & $1.67[0.45,6.21]$ & & & \\
\hline Kurbet et al (2018) & 3 & 20 & 3 & 20 & $16.5 \%$ & $1.00[0.23,4.37]$ & & & \\
\hline Total $(95 \%$ Cl) & & 145 & & 208 & $100.0 \%$ & $1.16[0.64,2.09]$ & & & \\
\hline Total events & 18 & & 25 & & & & & & \\
\hline $\begin{array}{l}\text { Heterogeneity: } \mathrm{Ch}^{2}=4 . \\
\text { Test for overal offect: } \mathrm{Z}\end{array}$ & $\begin{array}{l}\mathrm{df}=5(\mathrm{P} \\
0.50(\mathrm{P}=\end{array}$ & $\begin{array}{l}=0.53) \\
0.62)\end{array}$ & $; 1^{2}=0 \%$ & & & & $\begin{array}{l}0.1 \\
\text { Favours [TVF] }\end{array}$ & $\begin{array}{l}10 \\
\text { Favours [DF] }\end{array}$ & $\begin{array}{l}0 \\
\mathrm{~F}]\end{array}$ \\
\hline
\end{tabular}

Figure 2

a Forest plot of the comparison between DF and TVF flap techniques for UCF. b Forest plot of the comparison between DF and TVF flap techniques for other comlications 
A

\begin{tabular}{|c|c|c|c|c|c|c|c|c|c|c|}
\hline Study or Subgroup & $\begin{array}{r}\text { TVF } \\
\text { Events }\end{array}$ & Iotal & $\begin{array}{r}\text { DF } \\
\text { Events }\end{array}$ & & Weight & $\begin{array}{l}\text { Risk Ratio } \\
\text { M-H. Flxed. } 95 \% \mathrm{Cl}\end{array}$ & & $\begin{array}{r}\text { Risk R } \\
\text { M-H. Fixes }\end{array}$ & $\begin{array}{l}\text { Ratio } \\
\text { d. } 95 \% \mathrm{CI}\end{array}$ & \\
\hline Babu et al (2013) & 1 & 21 & 4 & 62 & $33.9 \%$ & $0.74[0.09,6.24]$ & & & & \\
\hline Basavaraju et al (2017) & 0 & 26 & 1 & 57 & $15.9 \%$ & $0.72[0.03,17.01]$ & & & & \\
\hline Chatterjee of al (2004) & 0 & 29 & 0 & 20 & & Not estimable & & & & \\
\hline Dhua of al (2012) & 0 & 25 & 0 & 25 & & Not estimable & & & & \\
\hline Gajbbiye et al (2018) & 0 & 24 & 0 & 24 & & Not estimable & & & & \\
\hline Kurbet et al (2018) & 3 & 20 & 3 & 20 & $50.2 \%$ & $1.00[0.23,4.37]$ & & & & \\
\hline Total $(95 \%$ Cl) & & 145 & & 208 & $100.0 \%$ & $0.87[0.28,2.70]$ & & & & \\
\hline Total events & 4 & & 8 & & & & & & & \\
\hline \multicolumn{7}{|c|}{$\begin{array}{l}\text { Heterogeneity: Chi }=0.07, \text { df }=2(P=0.96) ;\left.\right|^{2}=0 \% \\
\text { Test for overall effect: } Z=0.25(P=0.80)\end{array}$} & 0.01 & $\begin{array}{l}0.1 \\
\text { Favours [TVF] }\end{array}$ & Favours [D & $\begin{array}{l}10 \\
\text { DF] }\end{array}$ \\
\hline
\end{tabular}

B

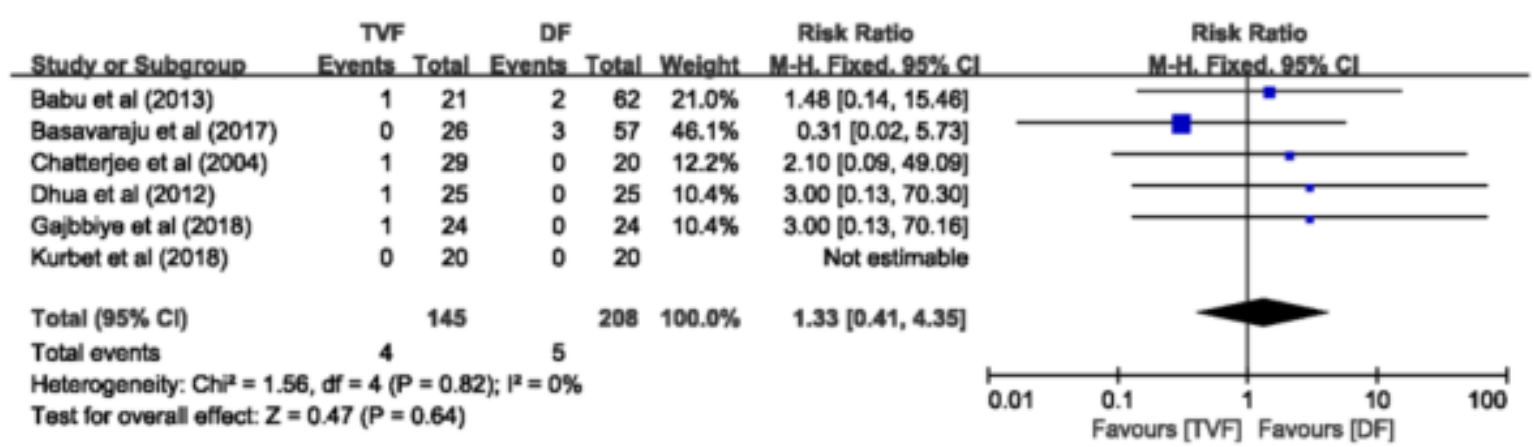

C

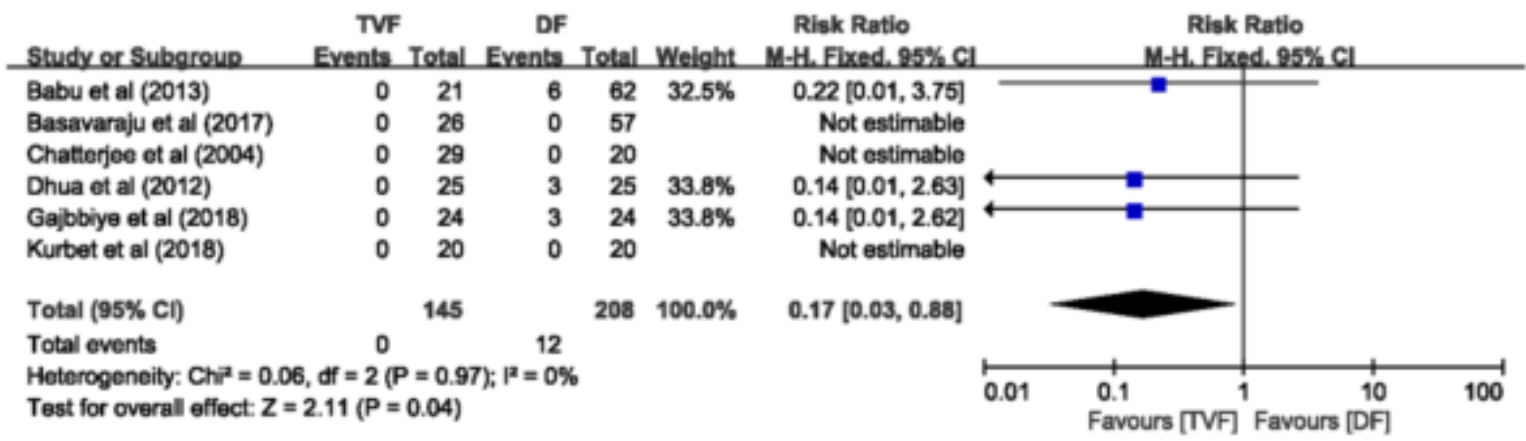

\section{Figure 3}

a Forest plot of the comparison between DF and TVF flap techniques for meatal stenosis/urethral stricture. b Forest plot of the comparison between DF and TVF flap techniques for glans dehiscence/wound dehiscence. c Forest plot of the comparison between DF and TVF flap techniques for skin necrosis 


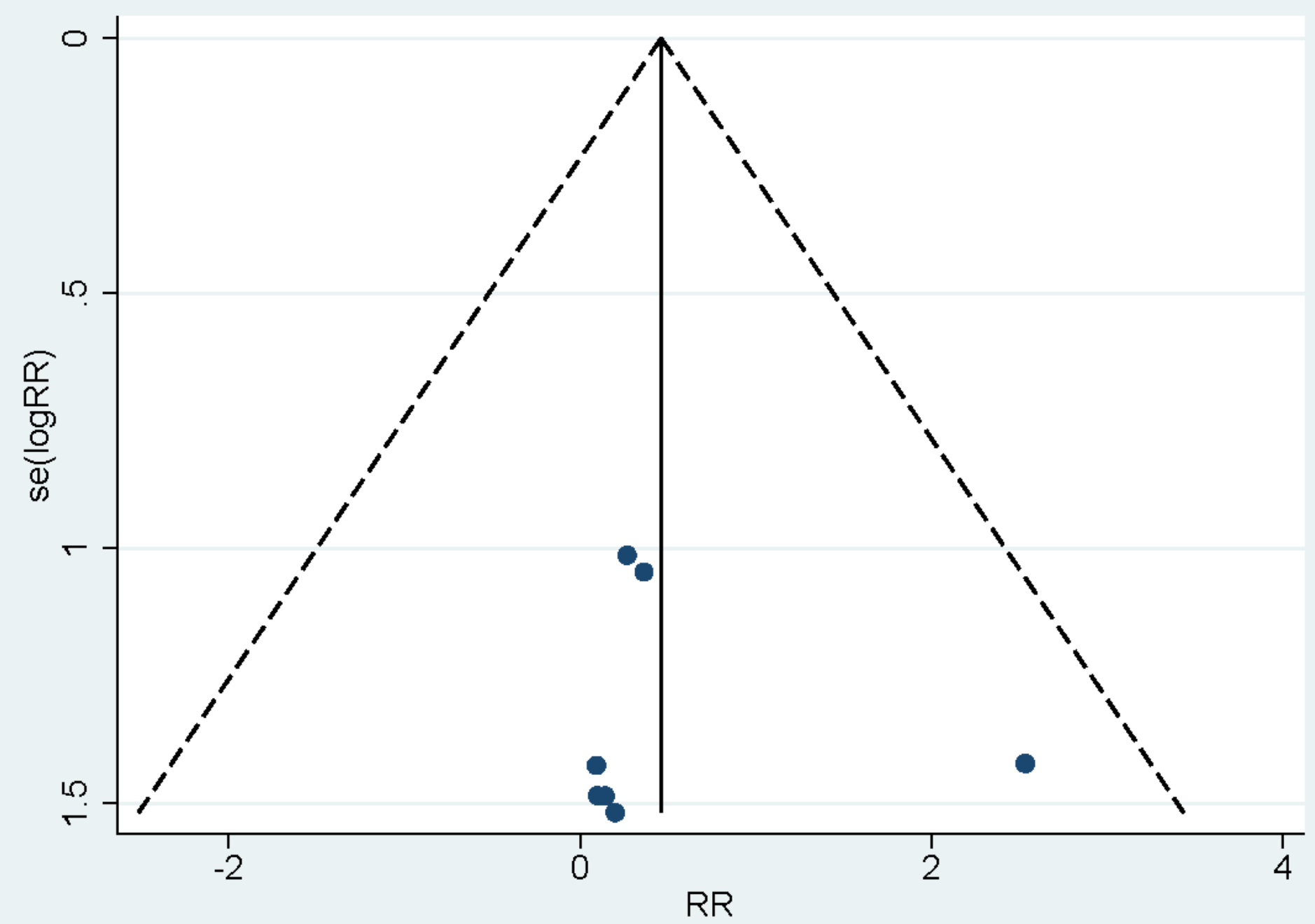

Figure 4

Funnel plot of the incidence of UCF

\section{Supplementary Files}

This is a list of supplementary files associated with this preprint. Click to download.

- Additionalfile1FigureS1Sensitivityanalysis.docx

- Additionalfile2TableS2PRISMAChecklist.doc 